\title{
Research on the Influence of Teachers' Scientific Research Ability on Students' Job Opportunity and Competitiveness
}

\author{
Ying Yan* \\ Tianjin University of Technology and Education \\ Tianjin, China
}

\author{
Haiyun Gan \\ Tianjin University of Technology and Education \\ Tianjin, China
}

\begin{abstract}
Against the background of the increasingly demanding employment of college students, how to improve the competitiveness of graduates from average universities has become a research focus in personnel training of higher education. The relationship between teachers' scientific research ability and employment competitiveness of students had been discussed based on the employment situation of the vehicle engineering department of Tianjin University of Technology and Education. Studies have shown that teachers with strong scientific research skills can improve student employment rates about $20 \%$ higher than the average of the entire department through classroom instruction, instructing students to participate in technology competitions and off-campus internships. It is a feasible way to increase the employment competitiveness of students through activating the teacher's research vitality which can broaden their scope of knowledge.
\end{abstract}

Keywords-employment; average universities; personnel training; research vitality

\section{INTRODUCTION}

There are more than 3,000 colleges and universities in China, of which only one hundred is key university[1]. This means that non-key universities account for more than $95 \%$ has assumed the vast majority of social talent training tasks. In the context of society's rising expectations for the employ ability of university graduates, employment pressure for graduates from average universities is huge[2][3]. At the same time, the threshold for recruiting teachers in universities is getting higher and higher. Even entering these average universities, most of them require doctoral degrees or above from key universities[4]. These newly recruited teachers all experienced good research training during their doctoral studies. Under this background, it is a problem that has to be solved in the process of personnel training in colleges and universities that how to transform their research ability into the employment competitiveness of students[5]. The author's college had been made as a survey model to study the influence of teachers' scientific research ability on students' employment competitiveness.

\section{BACKGROUND}

\section{A. School situation}

Established in 1979, Tianjin University of Technical and Education is the only university in Tianjin that is jointly supported by the Chinese Ministry of Education and Tianjin government. It has been formed mainly by engineering and pedagogy. It ranks around 500th in the country's 3,000 colleges and universities, which mean a typical average university.

\section{B. Teachers situation}

The author is one member of the vehicle engineering department with a total of 10 teachers. Among them, five teachers, with an average age of 45 or older, are basically teaching. There are also another 5 young teachers with ages of 32-39 (Serial No. A-E), who focused on many research projects. All these five teachers have doctoral degrees, as shown in Table I. Those scientific research projects have both been sponsored by the national or local government funds besides companies. It proved that these five teachers have higher scientific research ability compared to the average level. The main research directions include electronic control of new energy vehicles, intelligent cars, automotive NVH matching, and auto parts quality management. These are hot areas in the automotive industry. Its cooperation company includes China Automotive Technology and Research Center, Tianjin FAW Toyota Motor Co., Tianjin Bool Technology Co., Ltd., and Tianjin University including scientific research institutes, universities, vehicle manufacturers and suppliers.

TABLE I. BACKGROUNDS OF ACADEMIC CREDENTIALS

\begin{tabular}{|c|c|c|c|}
\hline No & Age & Academic credentials & University \\
\hline A & 32 & Doctor & Tianjin University \\
\hline B & 34 & Doctor & Jilin University \\
\hline C & 37 & Doctor & Tianjin University \\
\hline D & 38 & Doctor & Beijing Institute of Technology \\
\hline E & 39 & Doctor & Jilin University \\
\hline
\end{tabular}

In the past three years, the total research fund of these five teachers was shown in Fig 1 and the total number of research project was listed in Table II. It had been proved that these five teachers have much higher research ability and resource than the left ones in vehicle engineering department. 
TABLE II. NUMBER OF RESEARCH PROJECT (2015-2017)

\begin{tabular}{|c|c|c|}
\hline & A-E & Total department \\
\hline Num of research project & 26 & 35 \\
\hline National projects & 2 & 2 \\
\hline Local government sponsored & 2 & 3 \\
\hline Company sponsored & 22 & 30 \\
\hline
\end{tabular}

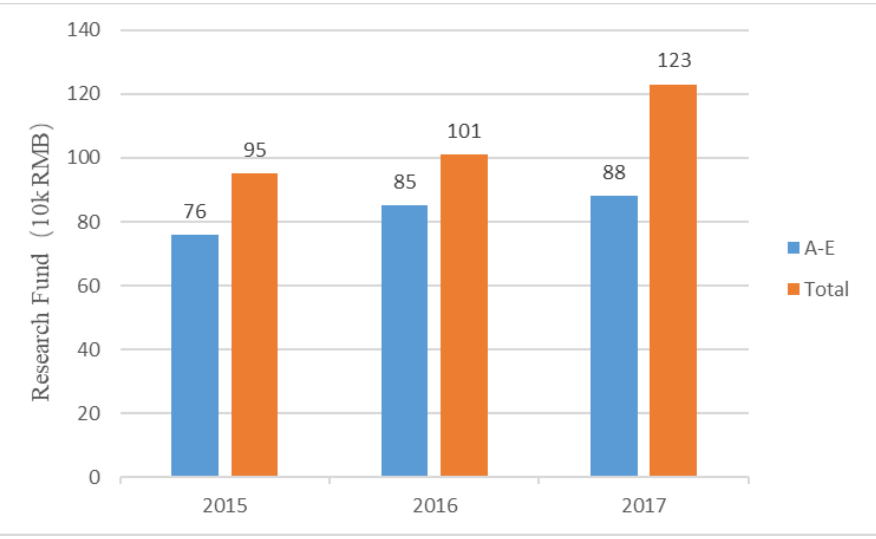

Fig. 1. Research fund proportion of the entire department

\section{Student situation}

The department of vehicle engineering has two classes, with an average of 73 students per year, including about 60 male students. Relative employment companies include automobile factories, advanced vocational schools and automobile components suppliers. The employment rate is basically stable at about $68 \%$.

\section{ANALYSIS}

\section{A. Teaching performance}

They were two ways to make an evaluation about teaching performance including a real-time teaching performance evaluation system and annual scoring mechanism[6]. The course taught by these five teachers includes automotive electronics, new energy automotive technology, automotive theory, automotive quality management. From Fig 2 and Fig 3, it can be seen that teachers with strong scientific research ability will introduce industry trends into the class, and students also welcome this teaching mode.

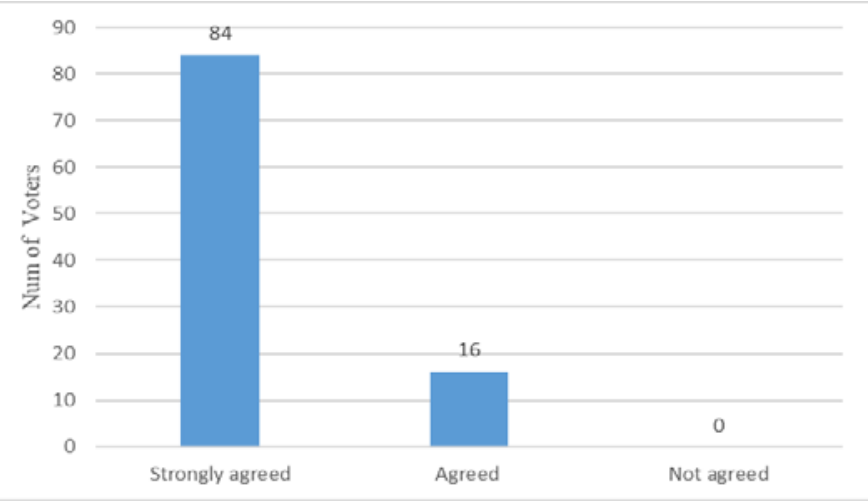

Fig. 2. Introduce industry trends into the class

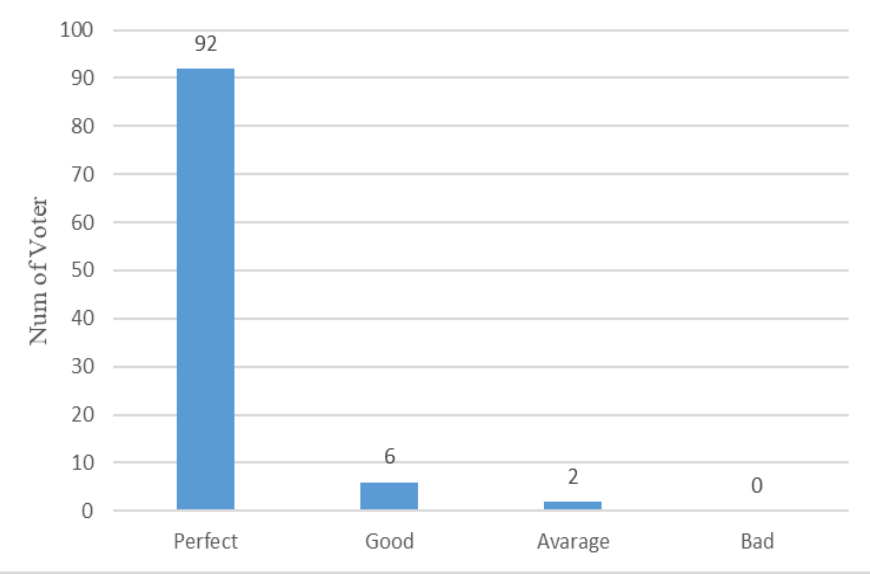

Fig. 3. Teaching performance evaluation

The statistical results of the annual teacher evaluation score were listed in Table III in the past 3 years. From the table, it can be seen that the overall teaching effectiveness of the teachers with strong scientific research ability is much higher than average of the college teachers. This shows that there way of teaching was accepted by the students. Students want to know the development of the industry. This is helpful to stimulate students' interest in learning and bringing students into the front line of the industry. Thereby enhancing their competitiveness in employment.

TABLE III. NUMBER OF RESEARCH PROJECT (2015-2017)

\begin{tabular}{|c|c|c|c|}
\hline & 2015 & 2016 & 2017 \\
\hline Average scores of A-E & 91 & 92 & 91 \\
\hline Average scores of total department & 82 & 81 & 83 \\
\hline
\end{tabular}

\section{B. Influence analysis}

In addition to the influence of the teaching process, the teachers' scientific research capabilities also improve the employment competitiveness of students in the following three areas.

\section{1) Research activities}

The teacher separates some of the tasks from the research projects to the undergraduate. Teachers personally tutor students to take part in actual scientific research projects. Students use what they have learned in actual research and development to enhance their hands-on capabilities. Students taking part in such activities are highly motivated and responsible for things. This quality is valued by the employer company. Therefore, its employment competitiveness has been improved. The following table shows statistics on the employment situation of students participating in research activities in the past three years. It can be seen that the student employment salary and employment success rate involved in this activity is more than average. 


\section{TABLE IV. EMPLOYMENT DATA}

\begin{tabular}{|l|c|c|c|}
\hline & 2015 & 2016 & 2017 \\
\hline \multicolumn{1}{|c|}{ Number of sample students } & 9 & 11 & 10 \\
\hline $\begin{array}{l}\text { Employment success rate of the } \\
\text { department }\end{array}$ & $70 \%$ & $67 \%$ & $71 \%$ \\
\hline $\begin{array}{l}\text { Employment success rate of the } \\
\text { sample students }\end{array}$ & $88 \%$ & $100 \%$ & $100 \%$ \\
\hline Average salary of the all students & 3451 & 3621 & 3713 \\
\hline Average salary of the sample students & 4205 & 4308 & 4561 \\
\hline
\end{tabular}

\section{2) Guiding competitions}

Teachers with strong scientific research skills often have rich technical resources. This includes social resources, school research and development equipment resources and accumulated technical resources[6][7]. Statistical data of the students of the department of vehicle engineering participated in the technical competition in the last three years can be found in the following table.

TABLE V. COMPETITION PARTICIPATOR VS EMPLOYMENT RATE

\begin{tabular}{|c|c|c|c|c|c|c|}
\hline & \multicolumn{2}{|c|}{2015} & \multicolumn{2}{c|}{2016} & \multicolumn{2}{c|}{2017} \\
\cline { 2 - 7 } & Num & Rate & Num & Rate & Num & Rate \\
\hline Formula Student China & 6 & $83 \%$ & 6 & $100 \%$ & 6 & $83 \%$ \\
\hline $\begin{array}{c}\text { National Undergraduate } \\
\text { Electronic Design } \\
\text { Contest }\end{array}$ & 8 & $87 \%$ & 8 & $75 \%$ & 4 & $100 \%$ \\
\hline $\begin{array}{c}\text { National Undergraduate } \\
\text { CAD Design Contest }\end{array}$ & 3 & $100 \%$ & 4 & $75 \%$ & 4 & $75 \%$ \\
\hline
\end{tabular}

\section{3) Graduation project}

The final semester of the student's senior year consists of a 4-week graduation practice and a 12-week completion design. After investigation, it was found that the five teachers were responsible for the graduation practice and graduation design of 42 students each year. Most of these students worked in companies.

TABLE VI. EMPLOYMENT RATE OF ST UDENTS WITH COMPANY EXPERIENCE

\begin{tabular}{|c|c|c|c|}
\hline & 2015 & 2016 & 2017 \\
\hline $\begin{array}{c}\text { Employment success rate of the } \\
\text { department }\end{array}$ & $70 \%$ & $67 \%$ & $71 \%$ \\
\hline $\begin{array}{c}\text { Employment success rate of the } \\
\text { students with company experience }\end{array}$ & $83 \%$ & $97 \%$ & $90 \%$ \\
\hline
\end{tabular}

A total of 89 students had finished their graduation project in a company which involved research institutes, universities, vehicle manufacturers and suppliers as showed in Fig 4.

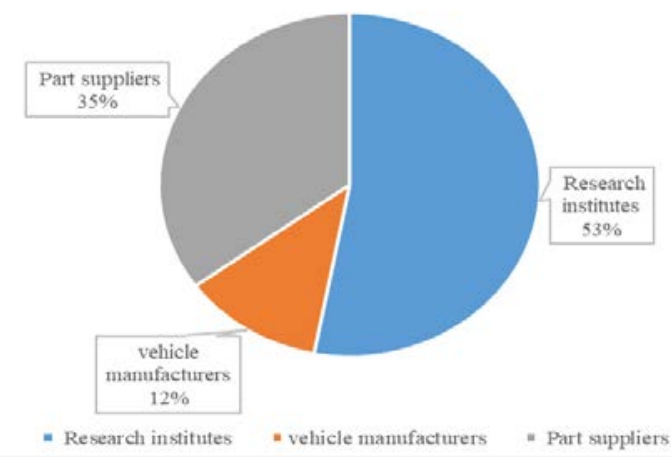

It can be seen that these students got much higher evaluation scores from the employers than the college's average score of all students.

\section{TABLE VII. EVALUATION SCORES ABOUT WORKING ABILITY}

\begin{tabular}{|c|c|c|c|}
\hline & 2015 & 2016 & 2017 \\
\hline Evaluation scores of the department & 68 & 70 & 70 \\
\hline $\begin{array}{c}\text { Evaluation scores of the students } \\
\text { with company experience }\end{array}$ & 75 & 78 & 80 \\
\hline
\end{tabular}

From the above table, we can see that the ability of the students to perform the curriculum work has been accredited by the company. Its score is significantly greater than the average. Students trained in this course model received a welcome from the company. The fundamental reason lies in shortening the time gap from school to job and reducing the training cost of the company[8][9].

\section{CONCLUSION}

Against the background of the slowing down of the development speed of the auto industry and the increase of employment pressure, colleges and universities should strongly encourage teachers to participate in scientific research and improve their scientific research capabilities. This will offer great benefit to improve the employment competitiveness of students. The students are also very willing to get to know the latest developments in the industry. The more teachers' research business, the richer the industry vision and industry resources, and the more job opportunities and employment information for students.

\section{REFERENCES}

[1] Wang le. Innovation of Employment Guidance in Colleges and Universities under the New Media Environment(In Chinese). Journal of Jiangxi Vocational and Technical College of Electricity,2017,30(2):6063.

[2] Zhou Yuan, Zhao Gulping. The Study on Current Situation of Vocational Core Competence (In Chinese). JOURNAL OF WUXI INSTITUTE OF TECHNOLOGY,2018,17(2):89-92.

[3] Gaurav Nayyar. The quality of employment in India' s services sector: exploring the heterogeneity. Applied Economics, 2012, 44:4701-4719.

[4] Cathy Yang Liu. Employment concentration and job quality for lowskilled Latino immigrants. Jottrrml of Urban Affairs, 2015,33(2):117141.

[5] Yang Junliang. Exploration of "three-requirement law"” and "three model" of higher vocational education (In Chinese). Journal of Liaoning Technical University,2016,5:115-119.

[6] Huo Lijuan. Analysis of the Multiple Streams of Production-education Integration Policy: Matching, Coupling and Development (In Chinese). Chinese Vocational and Technical Education, 2018,(39)04,6-13.

[7] Liu Jie. The study on the application path of mixed teaching in vocational colleges based on MOOC+SPOC+Rain Classroom (In Chinese). Vocational and Technical Education, 2018,14:5-11.

[8] He Lisha. Study on Innovative Development of Higher Vocational Colleges under the Background of "Double First-class" (In Chinese). Vocational and Technical Education, 2018,(39)04:39-44.

[9] Yang Zhuojuan, Fan Lidan, Zhao Jinling. On the Reconstruction of Professional Curriculum System in Applied Undergraduate Institutions Based on the School-enterprise Cooperative Innovation (In Chinese). Vocational and Technical Education, 2016,(37)29:17-19.

Fig. 4. Type of company 